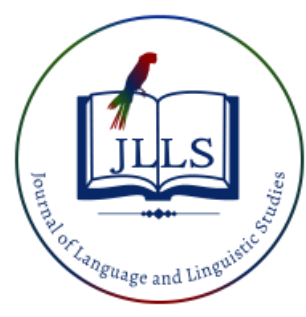

Available online at www.jlls.org

JOURNAL OF LANGUAGE

AND LINGUISTIC STUDIES

ISSN: $1305-578 \mathrm{X}$

Journal of Language and Linguistic Studies, 17(4), 1695-1715; 2021

\title{
Variations of impolite responses in YouTube Podcast videos
}

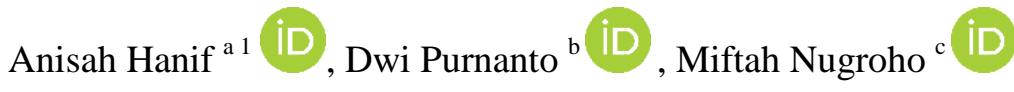 \\ ${ }_{a, b, c}$ Sebelas Maret University, Surakarta, Indonesia
}

\section{APA Citation:}

Hanif, A., Purnanto, D., \& Nugroho, M. (2021). Variations of impolite responses in YouTube Podcast videos. Journal of Language and Linguistic Studies, 17(4), 1695-1715. Doi: 10.52462/jlls.124

Submission Date: 06/04/2021

Acceptance Date: 20/06/2021

\begin{abstract}
This research looks at how speech partners react to language impoliteness in five YouTube podcast videos. The research data in a descriptive qualitative framework are authentic or natural in the form of spoken conversations between presenters and guest stars that include impoliteness responses. The five titles of Deddy Corbuzier's YouTube podcast videos served as the data source. The research method consists of note-taking and orthographic transcription, both of which employ a free-competence technique. The method of data analysis used was pragmatic and contextual matching. The research's findings reveal three types of responses from speech partners when confronted with language impoliteness. There are several representative variations in each of the response categories. The basis of distinguishing elements is primarily concerned with variations. Offensive countering is a response variation in which the speaker responds with curses as an expression of annoyance, ignores, or dismisses the speech partner. Defensive countering defines one's position in interactions by considering innocence, seeing oneself as distinct from others (more important than others), and demonstrating an action that places oneself in a safe situation. Face attack response attempts to accept impolite acts, confirm the speech partner's accusations, and work out solutions with the speech partner.
\end{abstract}

Keywords: variation; response; impoliteness act; podcast; pragmatics

\section{Introduction}

Pragmatics research has a tendency to focus on the speakers rather than the speech partners. This growing concern demonstrates the relevance of pragmatic research to speech acts, language politeness, and impoliteness. The basic concepts of using speech act, politeness, and impoliteness revolve around the interactions of the speakers. The importance of a speaker's point of view in pragmatic research is closely related to a relationship between information interpretation and speech context (Yule, 1996), and a wide range of interpretations leads to communication problems in everyday life (Rahardi, 2020). In this sense, regardless of communication barriers, the speaker's intent is an integral part of a pragmatic context of interactions. The meanings conveyed by the speech partner's utterances serve to deliver communication purposes. Conversational utterances include not only the speakers and speech partners, but also the contextual meanings behind them. Thus, the relationship between languages and

\footnotetext{
1 Corresponding author.

E-mail address: anisahhanif41@gmail.com
} 
their contexts forms the foundation for a pragmatic study that considers potential difficulties arising from linguacultural expressions and their communication contexts (Liu, Han, Kádár, \& House, 2021).

The most important aspect of pragmatic studies is context. Levinson (1997) emphasizes the importance of appropriately using utterances in a wide range of contexts. Pragmatic studies are based on language users' ability to correctly adapt sentences to contexts. If the speaker can effectively convey the message to the speech partner, communication will be smooth. Nugroho (2009) argues that the pragmatics or pragmatics force is entirely dependent on the contexts of speech acts. In this definition, speech partners in pragmatic research play the role of information recipients. It may convert information into interpretations in order to generate the intent of the speech act. The perspectives of speech partners and their contextual utterances are a significant gap in this pragmatic research. Worse, the lack of current research in this field widens the gap in terms of speech acts, politeness, and impoliteness. As a result, this pragmatic study focuses on speech partners' responses to language impoliteness.

The standard of speech acts in society has been widely determined by research on language politeness. People use polite languages to gauge the politeness of their interactions. However, impoliteness predominates in social interactions, as evidenced by studies by Maryani, Rusminto (2013), Indra (2013), Wijayanto (2014), and Yalmiadi (2014). (2014). The use of impolite language is determined by the speakers and their reasons for speaking in an impolite manner (Nuraini 2014; Sigit Haryanto, 2015; Ahmad Maulidi, 2915; Yustina Jumadi, 2015; Muhammad Ariz, 2016; Yosi, 2016). Most studies investigate the theory of violation of Leech's politeness maxims, as well as pragmatic features that investigate their diacronic developments (House \& Kádár, 2021).

Researchers underestimate this language immodesty. This language immodesty is underappreciated by researchers. They have politeness concepts without realizing that impoliteness concepts have transformed trends in the digital era. The use of everyday language in digital media has been incorporated into language impoliteness. Recently, some research has been conducted on language impoliteness (Azma, 2016; Mahbub, 2017; Wigati, 2017; Widara, 2018; Wijayanto, 2018; Shinta, 2018; Rinzat, 2018; Suryanti, 2019; Tasliati, 2019; Elen, 2019). This phenomenon is consistent with language users demonstrating greater freedom of expression on a variety of online and offline platforms that have penetrated digital technologies in Indonesia. Consequently, more research on impoliteness is needed, and it will have an impact on users and language use.

\subsection{Literature Review}

\subsubsection{Pragmatics}

According to experts, pragmatics can be defined in a variety of ways. Yule (1996) defines pragmatics as the study of the speaker's meaning. In this regard, George Yule emphasizes pragmatics as a study of a speaker's intent. The pragmatic study is primarily concerned with the relationship between information interpretation and the speakers' utterances to speech partners in a speech context. It is the study of the interaction between linguistic forms and their users. The advantage of learning language through pragmatics is that a person can speak words while considering pragmatic knowledge (Makin, 2021) involving meanings, assumptions of speech partners, intentions or goals, and actions demonstrated while speaking.

Leech (in M.D.D. Oka's translation, 1993: 8) defines pragmatics as the study of meaning in speech situations. Leech considers pragmatics to be a branch of linguistics that is related to semantics. This relationship is known as semanticism, which considers semantics to be a subset of pragmatics. Pragmatism is a subset of complementarianism, which refers to semantics and pragmatics as two complementary fields. According to Leech (1983), pragmatic studies deal directly with the core 
function of language in communication, focusing on the problems of using language in a community and revealing how a language community's language behavior socializes (Longman, 1963).

Mey (1993) states that pragmatics is the study of the conditions of human language use in society. As a result, pragmatic studies concentrate on language use in real and natural settings, including speakers and speech partners. Subroto (1999) adds that pragmatics is the semantics of intent. In some ways, pragmatics and semantics are similar in that they both investigate meaning. The difference between the two sciences is that pragmatics defines linguistic units externally, whereas semantics investigates the exploration of linguistic units internally. In this case, contexts involve the meaning of the linguistic unit externally. Subroto (2017) investigates the origins of pragmatic studies and considers it to be one of the fields of linguistic studies that has recently been rapidly developing. The utterance that is discarded because it cannot be analyzed linguistically has now become fertile ground in pragmatic studies. In pragmatic studies, the approach is based on the belief that meaning is highly dependent on context and language use. Speakers cannot comprehend the meaning of a speech in the absence of context.

Pragmatics is the study of the meaning of an utterance. Pragmatics is the study of the meanings of speakers' utterances and how speech partners comprehend them. Furthermore, the meaning of an utterance is influenced by the speakers, speech partners, and contexts. Thus, the study of pragmatics is based on the relationship between languages and context.

\subsubsection{Impoliteness Act}

Impoliteness is defined by Culpeper (2008) as a communicative behavior that results in the loss of the speech partner's face. This definition outlines impoliteness defined as behavior that causes the speech partner to lose face as a result of the speaker's utterances. Culpeper emphasizes that interaction between speakers and speech partners is inextricably linked to various contexts. Impoliteness occurs in communication when the speaker intends to attack the speaker's partner. They both engage in attacking behavior, or a combination of the two. In terms of impolite language, the speech partner either responds to the attacking behavior or remains silent. Most studies ignore the speech partners because they are only concerned with the speaker's impoliteness. From the perspective of a speech partner, it does not rule out the possibility of discussing how the speech occurs and other reasons for the linguistic incantation. The offensive-defensive and offensive-offensive responses of the speech partner to language impoliteness are offensive-defensive and offensive-offensive.

Culpeper, et al. (2003) argue that a recipient of an utterance perceives a strategic impoliteness act, also known as an exacerbated face-threatening act (FTA). There are two options for dual linkage: respond to or do not respond to the attacking behavior. The option of responding to language impoliteness remains open and unrestricted. It is up to the speech partners to decide how to respond to acts of impoliteness. They have the option of accepting the attack or confronting it. When assessing impoliteness, the response of speech partners or sufferers to the face-threatening attack (FTA) is frequently overlooked. Meanwhile, the response of conversation partners is important to understand how and to what extent the speech partner receives acts of impoliteness.

Labov's research (1972) assumes that personal insults can be identified by the way a person responds to such insults. Personal embarrassment was followed by rejection (Labov, 1972). In contrast, Harris' (1986) research on verbal aggression observes the same thing, assuming that the best way to save face from verbal attacks is to fight or attack. In addition, Culpeper's (2003) research explains that a recipient of an utterance perceives a strategic impoliteness act known as an exacerbated face-threatening act (FTA). Two options may result in either responding or not responding at all (staying silent). Furthermore, if a person chooses to respond to such an attack, he or she has two options: offensive or defensive. 
Culpeper (2003) suggests that there are several ways to respond to impoliteness. When an impolite act occurs, the speech partner has two options: respond to the speech situation or not respond at all. When the speech partner responds to language impoliteness, he or she has two options: fight (counter) or accept it. The speech partner fights (counters) language impoliteness, and the speech partner has two options: RES-CON-OFF and RES-CON-DEF. When the speech partner chooses to attack or fight back against the impolite speaker, this is referred to as Respond-Counter-Offensive (RES-CON-OFF). In a speech situation, respond-counter-defensive (RES-CON-DEF) occurs when the speech partner defends himself or herself in response to the language impoliteness.

Impolite language is now common in digital media. Many internet users become accustomed to internet media because of its convenience and unlimited access. Digital platforms are sources of language data. Podcasts, for example, have grown in popularity as a platform for demonstrating and potentially influencing how a language is used in society. Podcasting is a method of disseminating audio recordings via the internet (Walton et al., 2005). Podcasting begins with efforts to create and compress content using audio devices such as computers, microphones, recording software, audio, and compression software (Meng, 2005). The creation of podcasts with potential content is one of the most difficult processes. The created file will be uploaded to an internet-accessible web server. A corrupted file is turned into a podcast episode. The data source includes a time quote, allowing for the use of natural language. This podcast's informal atmosphere also promotes the emergence of data.

\subsubsection{Context}

The importance of context in pragmatic studies cannot be overstated. It is difficult to study pragmatics without context. In Nugroho (2009), an understanding of Levinson's context is presented, along with several pragmatic-driven definitions of the context. The following is Levinson's definition of pragmatics as it relates to context.

(1) Pragmatics is the study of the grammatical or encoded in the linguistic structure relationships between language and context.

(2) Pragmatics is the study of the relationships between language and context, which serves as the foundation for an account of language understanding.

(3) Pragmatics is the study of language users' ability to match sentences to the context in which they would be appropriate.

Nugroho (2009) argues that pragmatics or pragmatics force is highly dependent on the context in which the speech is uttered in a speech event. Even though pragmatic studies are closely related to the context of the speech situation in order to find out the meaning behind the utterances, utterances or speech can only be seen from words alone.

Leech (1983) defines context as a component in speech situations. Context is defined as elements of a speech's physical and social environment. Leech adds context to background knowledge, which aids interlocutors in interpreting the speaker's intent.

Zamzani (2007) points out that pragmatic contexts can be divided into two types: those that are relatively general in effect or found in every language community, and those that are uniquely local in nature. The first context is the cultural context, and the second is the context of speech or the situational context, which naturally includes both physical and linguistic forms. The situation, speech, or conversation's context is related to a variety of factors. The speaker, the interlocutor, and the code or language used are the three conditions for emerging communication. Leech (1983) categorizes the situation's context into five domains: (a) greeter and greeter, (b) context of speech, (c) purpose of speech, (d) speech as a form of verbal activity, and (e) speech as a result of the verbal act. 
Huang (2007) defines context as any relevant features of the dynamic setting or environment in which a linguistic unit is systematically used. Context is classified into three types. The first is physical context, which refers to the arrangement of physical speech. Second, there is the linguistic context, which refers to the surrounding utterances in the same discourse. Third, consider the context of general knowledge. Based on these contexts, the third category, which refers to the context in general knowledge, namely general knowledge or shared knowledge, has the closest understanding to the pragmatic context. Thus, context is a selection of background assumptions shared by the speaker, and addressee meaning is a compilation of background assumptions shared by the speaker to the recipient as an integral part of the face-threatening context (Zhang \& Wu, 2020).

\subsection{Research questions}

This study intended to find the two research questions:

1. How do the options for the listener's responses on the use of impoliteness act in YouTube podcast videos?

2. How are variations on the listener's impolite responses identified?

\section{Method}

\subsection{Types of Data}

Archer divides data into two categories (Nugroho, 2013): authentic or natural data and generated data or data elicitation. Original data is classified into two types: written data and oral data. Several published texts, instructions, health posters or government leaflets, and newspaper articles are examples of written actual data. Field notes, broadcast data, and recorded data are examples of original nonverbal data. Data elicitation or generated data is not ideal. The reason for this is that people are unsure of what they would say or do in real-life situations. A discourse completion test, role play, and role enactment are among the data.

The actual data in this research describes nonverbal features because it is derived from the speaker's direct speech with the speech partner. The goal of the oral data is to elicit written information. The researchers can communicate the findings of this research to the readers. The data consists of impolite conversations in Deddy Corbuzier's Youtube Podcast videos. This original data was obtained from Deddy Corbuzier's YouTube podcast sources, which were previously recorded, downloaded, and saved. The data served as the foundation for developing research problems and objectives.

Authentic talk recording encompasses a wide range of communication technologies that necessitate equally diverse data collection methods. Text-based computer-mediated communication, such as email, discussion groups, or various chat forms, allows for simple collection of stored postings from a consenting participant, whereas voice and visual access necessitate more complex technology and recording arrangements (Markham, 2004). Researchers recorded interactions in ordinary face-to-face encounters rather than exploring various forms of technologically mediated interactions as sites for pragmatic research. Field notes, audio recording, and video recording were used for this research of speech acts. The scope, delicacy, and quantity of what these techniques allow to be recorded varies greatly. They are all bound by the rule that observation and recording are inherently perspectival, partial, and selective (Duranti, 1997). 


\subsection{Research Type}

This research is defined as a face-to-face interaction (an interaction in face-to-face media). This research is also an authentic discourse with everyday conversations, allowing the diction to be used more freely. It is demonstrated in everyday conversations by the absence of turn-taking. The guest stars and a host act as if they are conducting regular interviews and debating topics. Due to the lack of a moderator in charge of organizing Deddy Corbuzier's Youtube podcast program, the absence of turntaking resulted in the phenomenon of overlapping speech events. The concept of Deddy Corbuzier's YouTube podcast program is similar to an ordinary interview in which guest stars discuss current community issues. Guest stars are only given an outline of the issues being discussed, allowing the stories in this podcast program to unfold naturally.

\subsection{Data collection procedures}

Markham (2004) explains that communication technologies offer a variety of data collection methods. Communication via text-based computer intermediaries such as e-mail, discussion groups, or various forms of chat attempts to save a collection of posts with participant permission. Voice and visual access necessitate more complex recording technologies and settings.

Obtaining pragmatic data entails recording authentic conversations in Deddy Corbuzier's YouTube video recording. Video recording is more effective because it captures both audio and visual data. The visual aspect of the video can assist researchers in interpreting speech and clarifying interactions during a speech event. From an audio standpoint, it is insufficient because audiences cannot see the speakers' expressions, making data collection incomprehensible. The audio data allows audiences to see the intonation and tone of a speech event.

Kasper (2000) states that interactions, questionnaires, and personal reports were used to collect data in pragmatic research. Ordinary conversation and institutional interactions are represented by the actual discourse. Daily communication is inextricably linked to utterances in specific institutions.

\subsection{Data analysis}

The data analysis investigates contextual, means-end, pragmatic equivalents, and heuristic techniques. They most likely link the identity of existing contexts (Rahardi, 2005). Using a determining tool, researchers outline the identity of a specific lingual unit. This is known as the pragmatic matching technique. It aims to identify, for example, the language unit based on the reactions or consequences that occur or arise in the speech partner. In certain situations, the speaker will use the language unit when meeting the speech partner. The pragmatic matching technique is also used to analyze partner utterances (Sudaryanto, 1993).

\section{Results and Discussions}

\subsection{Offensive Countering Responses}

The speech partner's response to the speech partner's counterattack action is offensive countering or fighting face attacks. This response occurs when the speaker's speech partner disagrees with what the speaker says. The goal of this offensive countering response is to counterattack and remove the speaker's face from the impoliteness act, so that the speech partner feels victorious as a result of the backlash. The data variations in the data sources include the response that curses as an expression of annoyance, ignores, or dismisses the speech partner. The speaker utilizes evidence-based sentences, denies and blames the speech partner, responds with critical questions, expresses annoyance at the 
speech partner, and makes threatening utterances. The following is an example of offensive countering or cursing as an expression of frustration in Deddy Corbuzier's YouTube podcast program.

Context: When Deddy Corbuzier invited Uus to be a guest star in Deddy Corbuzier's YouTube podcast program, the speech incident occurred. This speech occurred during a discussion between two of them about Uus's new habit of defecating while drinking coffee and smoking. Deddy Corbuzier thought Uus's new activities or habits were a little off-putting and sloppy.

Data 1

Guest-UUS : In fact, the black coffee smoothed things out.

Host : Yes, but not right away.

Guest-UUS : Immediately. Each person's digestion is unique. You're 40 years old, so your digestion is bad!

\section{Host $\quad$ : Bastard! (8/NEG/UUS/OFF)}

In the case of the speech event, Data 1 contains an offensive counter-attack to Guest, UUS's face attacks, "Each person's digestion is unique. Your digestion is bad because you're 40 years old!" Deddy Corbuzier, the host, utilized an offensive counter-response strategy. He expressed his annoyance by yelling, "Bastard!" This swearing expression is a harsh counterpoint to the guest who attacked the host by assuming that people over the age of forty have poor digestion. Because the host is in his forties in this context, the guest refers to the host. This bastardly harsh word depicts a face attack on the guest, attempting to disagree with his point of view. As a result, Deddy Corbuzier's response had a high intonation and an annoyed tone. Thus, the bastard curse is used to respond to the guest's previous practice of language impoliteness with a mocking strategy.

The second variant of the offensive countering response is to attack back by ignoring or dismissing the speech partner. This response occurs as a result of speech partners' decision to ignore previous impolite speakers who attempted to undercut them. This action results in a loss of face because language impolite speakers are regarded as unimportant. The following is an example of speech event data that depicts variations in the use of offensive countering responses by ignoring or dismissing speech partners.

Context : Deddy Corbuzier and his guest star, Ivan Gunawan, were both involved in the speech incident. Ivan Gunawan has known Deddy Corbuzier for a long time. He apprehended Deddy Corbuzier, who did not follow him on Instagram.

Data 2

Guest-IG : $\quad$ This is a noisy person, huh.

Host : What is the point of following you on Instagram? (3/BOR/IG/OFF)

In Data 2, the guest performed an impoliteness act while drilling through the speech "This is a noisy person, huh." This person's remark is directed at Deddy Corbuzier because Gunawan regards himself as the host and owner of the podcast program. Deddy Corbuzier retorted to his guest star, asking, "What is the point of following you on Instagram?" Gunawan's frustrated expressions are intended to be ignored by Deddy Corbuzier's response. This response demonstrates that Gunawan's annoyance with him was deemed insignificant. In terms of power, both of them have a high level of power and have the ability to respond to language impoliteness. As a result, the two speech participants prefer to compete against each other to win the face attack so that they can demonstrate to the other party who is superior in counterattacking. 
Sentences show variations in offensive countering responses. The utterance is intended to emphasize that a speech partner spoke directly, offensively, and urgently. The attempt to counterattack the speech partner with proof aims to demonstrate truth in order to persuade other parties. This offensive counter-argument attempts to demolish the speaker's previous argument or accusation of impoliteness, causing him to lose face. An example of speech event data containing an offensive countering response is shown below.

Context : Deddy Corbuzier and Ivan Gunawan were involved in the speech incident. He suspected Deddy Corbuzier's beard was embroidered or that he used eye shadow to make it appear more masculine.

Data 3

Host : Why is it embroidered?

Guest-IG : Alas, your shit cat! Cat litter!

Host : "You hold it!" (While rubbing his hand against his beard)

Guest-IG : Your beard, huh. You put on your eye shadow, don't you?

Host : No! Not at all! (While rubbing his hand against beard). (7/BOR/IG/OFF)

Data 3 depicts a drilling strategy used in response to Gunawan's impoliteness act. The phrase "Alas, your shit cat! Cat litter!" implies that the host, Deddy Corbuzier, did not embroider his beard. This response reveals the truth, which is that offensive countering in imperative sentences seeks to disprove Gunawan's false accusations. While rubbing his beard, Deddy Corbuzier said "You hold it" in a higher tone to tell the truth directly.

The next offensively countering response variation was denying and blaming the speech partner. A counterattack in a speech seeks to refute this viewpoint. There is even a face attack as a result of a disagreement with the speech partner. Certain arguments seek to demonize the opposing party by blaming them. This may occur as a result of debates dealing with their counterattack responses.

Context : $\quad$ Deddy Corbuzier and his guest star, Onadio Leonardo, were both involved in the speech incident. Netizens have recently highlighted the appearance of too open women on social media. When this happened to his wife, Onadio tried to set a good example.

Data 4

Guest-OND : $\quad$ Indeed, you believe my wife appears to lack breasts... Okay, unless she's flipping small breasts (demonstration) to deter people from commenting.

Host : $\quad$ That's what you said, son of a bitch.

Guest-OND : $\quad$ Not at all, please! The netizens are the bastard. (9/POS/OND/OFF)

Data 4 captures a response to Onadio's impoliteness, such as "Indeed, you believe my wife appears to lack breasts... Okay, unless she's flipping small breasts (demonstration) to deter commenters." This language immodesty delineates a positive strategy of using harsh and disrespectful words derived from the human body part of the 'breasts' [toket]. This remark is made to defend his wife's behavior on social media, which has resulted in netizens' comments. Deddy Corbuzier denied and blamed Onadio in response to offensive countering. This arises as a result of disagreements between parties and opposing points of view. Deddy Corbuzier was also blamed because his perspective on Onadio was incorrect or was simply his way of thinking. This offensive counter-response seeks to deny and blame by utilizing the derogatory phrase "That's what you said, son of a bitch." This statement exemplifies a positive approach to using offensive and disrespectful language. Deddy Corbuzier spends the entire speech denying and blaming Onadio's understandings or ways of thinking. Swearing or cursing are 
impolite and harsh words. The term "dog" is derived from the name of an animal that used to attack the partner's face. The offensive counter-response deteriorates even further. The speaker employs a more aggressive intonation to convey a tone of denial and blame. The speech event data are equally high in terms of the power possessed by both of them, so they have the potential to attack each other by violating a politeness act.

The offensive countering response variant responds with embarrassing questions, resulting in speech partner's face-to-face silence. Most embarrassing questions use rhetorical questions to respond to offensive countering. Because of the difficult questions, other speech participants have missed out on the opportunity to respond. Rhetorical questions may also include satire or introspective materials for other speech participants who lack the knowledge or capacity to respond to them. The offensive countering response in the following speech event data is an angular rhetorical question.

Context : Deddy Corbuzier and his guest star, Minister of Justice and Human Rights Yasonna Laoly, were both involved in the speech incident. Deddy Corbuzier heard stories from other parties about the actual conditions of Indonesian prisons.

Data 5

Host : Please, bro, tell me some stories. I won't know if this is true or not until the toilet is gone. The feces (sorry, feces) oh, what a shit everywhere.

Guest-YAS: Yes, I know, I know.

Host : What's the matter? This implies that our prison facilities are inhumane.

Guest-YAS: That is, indeed, our problem. Why is this so? You may be aware that narcotics are abused in $53 \%$ of our prisons. As a result, both the offender and the criminal act are linked to narcotics. (1/BOR/YAS/OFF)

The event in Data 5 depicts a reaction to Deddy Corbuzier's impoliteness through the use of his utterance, "What's the matter? This implies that our prison facilities are inhumane." Yas countered the offensive with angular rhetorical questions, employing a drilling strategy. This is a section of Yas's speech. "That is, indeed, our problem. Why is this so? You may be aware that narcotics are abused in $53 \%$ of our prisons. As a result, both the offender and the criminal act are linked to narcotics." The rhetorical question is, "Why did it happen in prison?" This question rephrases what Deddy Corbuzier said about Indonesian prisons being inhumane.

Deddy Corbuzier lacks both capacity and understanding of the legal system. He needs to learn more about human rights and prison conditions. This remark appears to have caused Deddy Corbuzier to pause for a moment before declining to answer the question. The Minister of Law and Human Rights has served twice as much by preparing an answer to this rhetorical question in the same speech. He also knows that Deddy Corbuzier cannot answer this question because he is not interested in the law or human rights. The answer remains the same -53 percent of Indonesian prisons abuse narcotics in the sense that the offenders are drug addicts. Variations in the offensive countering response demonstrate the speech partner's annoyance. The party expresses resentment directly and makes an offensive counterattack against the partner. This counterattack aims to eliminate embarrassing or impolite behavior.

Context : Deddy Corbuzier and his guest star, Ivan Gunawan, were both involved in the speech incident. They have known each other for a long time. He claimed that Deddy Corbuzier did not follow him on Instagram. 
Data 6

Host : My question is... I'm an Instagram follower of yours. I notice them, but I don't notice you.

Guest-IG : Yes, but later. Never mind at all.

Host : No way, why do I follow you on Instagram? What is the purpose of it?

Guest-IG : You're a noisy person, here! (4/NEG/IG/OFF)

Data 6 is a retaliation for Deddy Corbuzier's impoliteness act, which aimed to attack Gunawan's face with a negative strategy of grabbing turn-taking through the utterance, "No way, why do I follow you on Instagram? What is the purpose of it?" This demonstrates that Gunawan has not completed his explanation. Gunawan's annoyance is directed directly at Deddy Corbuzier in the offensive counterresponse, "You're a noisy person, here!" The goal of this speech is to rearticulate the disruption in order to counterattack the interlocutor. Gunawan employs a strategy of positive impoliteness by ignoring speech partners, not answering, or ignoring the question. This attitude reflects the ignorance and frustration expressed by Gunawan and Deddy Corbuzier. Both serve to amplify the deep resentment.

Threatening speech is the final variant of the offensively countering response. To counterattack other parties, the option to respond to threatening speech acts is effective because other parties do things that differ from what they said, as well as the consequences. This speech partner intends to threaten others by doing things that are harmful, inconvenient, or injurious. This threatening speech also serves as a signal or warning about the possible attitudes that the responders will adopt. The speech event data represents offensive counter-responses or threatening utterances.

Context : Deddy Corbuzier and his guest star, Onadio Leonardo, were both involved in the speech incident. Onadio discovered that the Indonesian Broadcasting Commission censors animal parts on television.

Data 7

Guest-OND : The animal tits. In a blur, those animal breasts (while searching on Google).

Host : Because of what, exactly?

Guest-OND : Because they can excite the boys. I swear to God, huh.

Host : I strike you, dude! (18/POS/OND/OFF)

The speech event in Data 7 is a response to the impoliteness of language through Onadio's speech "Because they can excite the boys. I swear to God, huh." It has become a positive strategy to use harsh and impolite words derived from human sexual activity. The offensively countering responses are part of Deddy Corbuzier's speech, "I strike you, dude," which indicates a threat. As a result, if Onadio "lies," Deddy Corbuzier will hit him with his palm [tabok: Javanese]. Such utterances intend to threaten, which results in language impoliteness because it requires or urges proof of what has previously been uttered.

\subsection{Defensive Countering Response}

Defensive countering is a reaction to attacks that involves defending one's utterance and fighting evasively. In other words, a speech partner (interlocutor) defends the speaker's utterances by explaining or saying something true without attacking the speaker. Defending one's utterance by being innocent, seeing oneself as different from others (more importantly), expressing polite utterances, and 
showing actions that position oneself in a safe situation are four variations on the defensive response. An example of a defensive countermeasure is provided below.

Context : The incident occurred when Deddy Corbuzier invited Yasonna Laoly, Minister of Law and Human Rights. In the YouTube podcast, Deddy Corbuzier acted as a representative of the Indonesian people, aiming to criticize government policies, particularly the Minister of Law and Human Rights, Yasonna Laoly's policies on law and human rights. The condition of Indonesian prisons has already had the effect of bottle caps, as the number of prisoners has increased, despite the fact that the capacity of Indonesian prisons is insufficient. This occurs because the legal distinction between users and drug dealers remains skewed and ambiguous.

Data 8

Guest-YAS : Can you imagine? We're tired of taking care of this. We haven't been able to keep tens of thousands of people at the police station. And that will come later, because COVID-19 currently does not tolerate accepting it, except for those who do so. We've recently spent a lot of money, haven't we?

Host : This is beyond my understanding. You work as a minister. You have the authority; it is simple to resolve this. You have the authority to do so!

Guest-YAS : What's the reasoning? Because of the extraordinary crimes committed by BP 99, when I became a minister, I wanted to correct it. Corruption, terrorists, and drug dealers could all be fixed, but outsiders claimed that the Minister of Law and Human Rights wanted to defend corruptors. (5/NEG/YL/DEF)

Data 8 demonstrates a defensively countering reaction to defend one's argument by assuming someone is innocent, as reflected in Yasonna Laoly's utterances. When confronted with a conversational attack, the Minister corrected himself, stating that BP 99 was a particularly heinous crime. Deddy Corbuzier attacked him by rearticulating that he could do anything as a Minister. $\mathrm{He}$ possesses the ability to deal with extraordinary crimes. Because the Minister is currently in office, he is able to resolve legal and human rights issues. When the Minister attempted to defend his arguments by declaring himself innocent, he elicited a defensive counter-response. However, his efforts to keep the country safe from crime spark suspicion and debate in the community. His proposal to revise the narcotics law was denied.

The defensively countering response seeks to recognize that someone is unique from others (more importantly). This response is intended to demonstrate one's uniqueness or privileges in law enforcement. The following is the speech event data, which includes a defensively countering response based on those privileges.

Context : Deddy Corbuzier and his guest star, Ivan Gunawan, were both involved in the speech incident. Deddy Corbuzier remarked on Gunawan's attitude as if he had changed his business to become a meatball seller and project manager due to the impact of the COVID-19 pandemic. Deddy Corbuzier thought Ivan Gunawan's attitude was exaggerated.

Data 9

Host : Now I'm going to ask you a question. What if we've been fighting this pandemic for two years?

Guest-IG : It's difficult to devote yourself if you don't do anything. You don't have hallucinations in the first place. What are your plans for the next two years? It's 
insane. If it's been two years, I should go to the mountain and breed cattle or do something there.

Host : No, I'm still alive in this pandemic year.

Guest-IG : Yeah, you're! (24/NEG/IG/DEF)

Data 9 is a speech event response to the pandemic year's language impoliteness regarding business activities. Deddy Corbuzier chose a defensively countering response to distinguish himself from other people in general. He realized that responding to language impoliteness results in self-defense, with a chance of survival even though COVID-19 lasts two years. Gunawan, on the other hand, claimed that if the CCOVID-19 pandemic lasted two years, he would be unable to live in the city. Furthermore, the defensive response variant seeks to protect oneself from language impoliteness. The use of defensive responses is represented by the speech event data below.

Context : Deddy Corbuzier and his guest star, Ivan Gunawan, were both involved in the speech incident. He had a feeling Deddy Corbuzier had embroidered his beard.

Data 10

Guest-IG : Your hair doesn't look like a grandpa's hairstyle, Deddy.

Host : I polish my hair, dog!

Guest-IG : Oh my gosh! People called me a cow or even a dog, honey. (3/POS/IG/DEF)

Data 10 demonstrates a response to language impoliteness in which Deddy Corbuzier used harsh words throughout the speech, "I polish my hair, dog!" Gunawan chose the self-defense response of "Oh my gosh..." to express his surprise and sadness at his interlocutor's impolite words. Gunawan used the term "cow" to defend himself because he was bullied. The use of the phrase "a cow" refers to his chubby posture. He recognizes that it has been a mockery for his body posture, resulting in a conflation of the two.

The final defensive countering response variation depicts an action that places oneself in a safe position to support one's background and the issues under discussion. This type of response attempts to avoid impolite language usage. The data in the following example depicts self-defense responses by demonstrating actions that place oneself in a safe situation.

Context : Deddy Corbuzier and his special guest, Nadiem Makariem, Minister of Education and Culture, took part in the speech event. They talked about the effects of the COVID-19 pandemic on education.

Data 11

Host : Is there a generation in the world that is at a disadvantage?

Guest-NDM : It's not a debate. We must have witnessed it. Yes, there is a decline in learning quality. Because humans will not be able to adapt to this situation in a matter of months. Distance learning will take five or even ten transition years to achieve the best results.

Host : And we're not prepared for it?

Guest-NDM : Sure. It is also impossible for the entire world to achieve. We can say that the quality of learning is the same all over the world. But, Mr. Deddy, there is a spectrum. More mature college students are 15 years old or older, and they have had at least one year of a learning gap. Its impact will be less severe than that of the children who have already been exposed to it. (10/NEG/NDM/DEF) 
Data 11 shows that Deddy Corbuzier used a negative strategy of grabbing turn-taking through his question to Nadiem Makariem in response to the language impoliteness. "And we're not prepared for it?" Before Nadiem could finish his explanation, he was interrupted by a rebuttal from Deddy Corbuzier. To avoid further attacks, Nadiem used a defensive response, such as securing his argument or positioning himself in a safe location. Deddy Corbuzier had previously confronted him with the question, "Is there a generation in the world that is at a disadvantage?" Nadiem chose to respond to this defensive counter-argument by claiming that the quality of learning has recently deteriorated. It is impossible to adjust quickly to the COVID-19 pandemic learning difficulties. The use of this language insecurity highlights the pandemic's potentially disastrous effects on education.

\subsection{Accepting face-to-face attack response}

In addition to the option of a counter-response, participants can choose to accept face-to-face attacks or language impoliteness in order to discuss. In this case, the participants agree to the language impoliteness and interpret it as an attempt to gauge the level of face-to-face attacks. Accepting the impoliteness act, confirming the speech or accusing the speech partner, and using the solution are examples of variations. The response to accepting the face-to-face attack, confirming the speech, or accusing the speech partner is represented by the following example of speech event data.

Context : When Deddy Corbuzier invited Ivan Gunawan to participate in the YouTube podcast, the speech incident occurred. They talked about how to upload photos to their personal Instagram accounts, both of which had previously been edited so that the photograph appeared proportional.

Data 12

Guest-IG : Isn't it true that you also modified your appearance?

Host : Yes, I altered it as well. (4/BOR/IG/ACC)

Deddy Corbuzier, the host, responded to the speech impoliteness in Data 12 by accepting the impoliteness act, confirming the speech act, or accusing the speech partner. This idea stems from Gunawan's language impoliteness, "...you also modified your appearance?" because he discovered several photos that Deddy Corbuzier uploaded on Instagram that went through the editing processes. He responded by accepting the act's impoliteness. He edited some of his uploads to make them appear proportional. Because of the allegations leveled against him, his response to the face-to-face attack has a low intonation and a tone of regret. He attempted to locate his uploads and determine whether or not his interlocutor's accusations were true. They were having a difficult conversation (Matsumoto \& Canagarajah, 2020). The following diagram illustrates the summary of impoliteness responses between the host and the guest stars in the YouTube podcast videos. 


\section{Impolite Responses between the Host and the Guest Stars in the Youtube Podcast Videos}

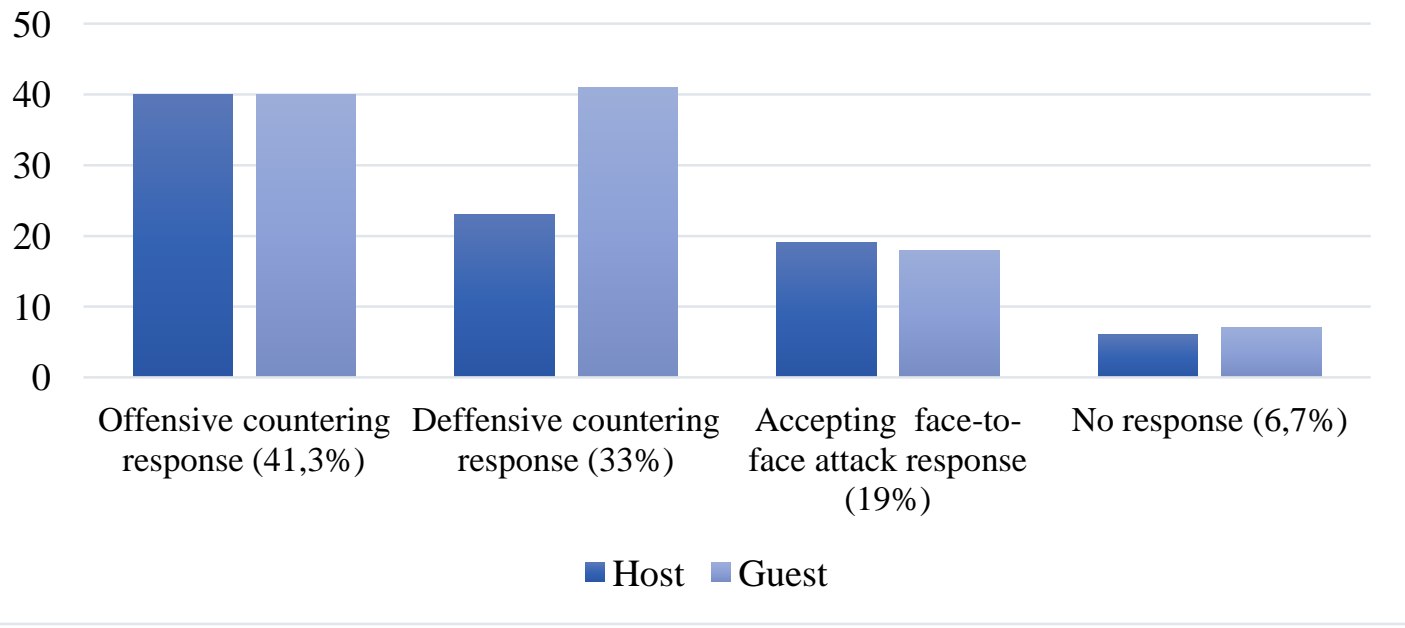

Other responses to language impoliteness are also available in Deddy Corbuzier's Youtube podcast videos. As many as 194 overall response data originating from 5 different podcast titles and guest stars were found in dealing with language impoliteness responses of speech partners. The first podcast's title, "Are you certain it's a boy? What happened to the makeup?" Finally, 54 data were discovered in the podcast video with the Guest Star, Ivan Gunawan. The second podcast, "Adult Content," with Onadio Leonardo as a guest, received 39 responses. The podcast's title is "He went completely insane. Djancok, sir!!" with the guest star Uus discovered up to 35 data points. In Indonesian slang, djancok refers to cursing when one's emotions spontaneously combust, one becomes angry, or one hates and curses someone. Fourth, a podcast featuring Yasonna Laoly, Minister of Law and Human Rights, with the title "Wow, it's insane! This is a prison. What the hell is going on?" We discovered 39 speech partners' response data, and finally, 27 data were discovered in the podcast "What if one generation is illiterate, bro?" with a guest star from the Minister of Education and Culture, Nadiem Makariem. To make it easier to understand, the table below depicts the distribution of types of speech partners' responses to language impoliteness based on the podcast title, including guest stars and language impoliteness responders or speech partners.

Table 2.1. The number of responses from speech partners to the use of indecent language in Deddy Corbuzier's YouTube podcast videos

\begin{tabular}{|l|l|l|l|l|}
\hline No & \multicolumn{1}{|c|}{ Podcast Titles-Guest Stars } & \multicolumn{1}{|c|}{ Responses } & \multicolumn{1}{|c|}{ Speakers } & \multicolumn{1}{|c|}{ Total } \\
\hline 1. & $\begin{array}{l}\text { Are you certain it's a boy? What } \\
\text { happened to the makeup?! In the } \\
\text { end, I got myself into a pickle } \\
\text { Ivan Gunawan }\end{array}$ & Responding by retaliating & $\begin{array}{l}\text { H: } 15 \\
\text { GS: } 9\end{array}$ & 24 \\
\cline { 3 - 5 } & $\begin{array}{l}\text { Maintaining your own face as } \\
\text { you respond }\end{array}$ & $\begin{array}{l}\text { H:10 } \\
\text { GS: } 10\end{array}$ & 20 \\
\cline { 3 - 5 } & $\begin{array}{l}\text { Accepting as the appropriate } \\
\text { response }\end{array}$ & $\begin{array}{l}\text { H: } 5 \\
\text { GS:3 }\end{array}$ & 8 \\
\cline { 3 - 5 } & Absence of response & $\begin{array}{l}\text { H:1 } \\
\text { GS:1 }\end{array}$ & 2 \\
\hline Total Response & $\begin{array}{l}\text { H: 31 } \\
\text { GS: 23 }\end{array}$ & $\mathbf{5 4}$ \\
\hline
\end{tabular}




\begin{tabular}{|c|c|c|c|c|}
\hline \multirow[t]{4}{*}{2.} & \multirow[t]{4}{*}{ Adult Content - Onadio Leonardo } & Responding by retaliating & $\begin{array}{l}\text { H: } 8 \\
\text { GS: } 6\end{array}$ & 14 \\
\hline & & $\begin{array}{l}\text { Maintaining your own face as } \\
\text { you respond }\end{array}$ & $\begin{array}{l}\text { H: } 5 \\
\text { GS: } 9\end{array}$ & 14 \\
\hline & & $\begin{array}{l}\text { Accepting as the appropriate } \\
\text { response }\end{array}$ & $\begin{array}{l}\mathrm{H}: 4 \\
\text { GS: } 4\end{array}$ & 8 \\
\hline & & Absence of response & $\begin{array}{l}\text { H: } 3 \\
\text { GS: } 0\end{array}$ & 3 \\
\hline \multicolumn{3}{|c|}{ Total Response } & $\begin{array}{l}\text { H: } 20 \\
\text { GS: } 19\end{array}$ & 39 \\
\hline \multirow[t]{4}{*}{3.} & \multirow[t]{4}{*}{$\begin{array}{l}\text { He went completely insane. } \\
\text { Djancok, sir! - Uus }\end{array}$} & Responding by retaliating & $\begin{array}{l}\text { H: } 9 \\
\text { GS: } 10\end{array}$ & 19 \\
\hline & & $\begin{array}{l}\text { Maintaining your own face as } \\
\text { you respond }\end{array}$ & $\begin{array}{l}\text { H: } 5 \\
\text { GS: } 3\end{array}$ & 8 \\
\hline & & $\begin{array}{l}\text { Accepting as the appropriate } \\
\text { response }\end{array}$ & $\begin{array}{l}\text { H: } 4 \\
\text { GS: } 2\end{array}$ & 6 \\
\hline & & Absence of response & $\begin{array}{l}\text { H: } 1 \\
\text { GS: } 1\end{array}$ & 2 \\
\hline \multicolumn{3}{|c|}{ Total Response } & $\begin{array}{l}\text { H: } 19 \\
\text { GS: } 16\end{array}$ & 35 \\
\hline \multirow[t]{4}{*}{4.} & \multirow[t]{4}{*}{$\begin{array}{l}\text { Wow, it's insane! This is a prison. } \\
\text { What the hell is going on? - } \\
\text { Yasonna Laoly }\end{array}$} & Responding by retaliating & $\begin{array}{l}\text { H: } 5 \\
\text { GS: } 6\end{array}$ & 11 \\
\hline & & $\begin{array}{l}\text { Maintaining your own face as } \\
\text { you respond }\end{array}$ & $\begin{array}{l}\text { H: } 3 \\
\text { GS: } 9\end{array}$ & 12 \\
\hline & & $\begin{array}{l}\text { Accepting as the appropriate } \\
\text { response }\end{array}$ & $\begin{array}{l}\text { H: } 5 \\
\text { GS: } 6\end{array}$ & 11 \\
\hline & & Absence of response & $\begin{array}{l}\text { H: } 1 \\
\text { GS: } 4\end{array}$ & 5 \\
\hline \multicolumn{3}{|c|}{ Total Response } & $\begin{array}{l}\text { H: } 14 \\
\text { GS: } 25\end{array}$ & 39 \\
\hline \multirow[t]{4}{*}{5.} & \multirow[t]{4}{*}{ 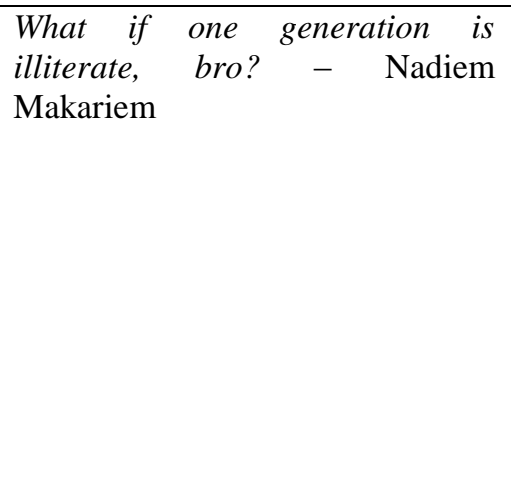 } & Responding by retaliating & $\begin{array}{l}\text { H: } 3 \\
\text { GS: } 9\end{array}$ & 12 \\
\hline & & $\begin{array}{l}\text { Maintaining your own face as } \\
\text { you respond }\end{array}$ & $\begin{array}{l}\text { H: } 0 \\
\text { GS: } 10\end{array}$ & 10 \\
\hline & & $\begin{array}{l}\text { Accepting as the appropriate } \\
\text { response }\end{array}$ & $\begin{array}{l}\text { H: } 1 \\
\text { GS: } 3\end{array}$ & 4 \\
\hline & & Absence of response & $\begin{array}{l}\text { H: } 0 \\
\text { GS: } 1\end{array}$ & 1 \\
\hline \multicolumn{3}{|c|}{ Total Response } & H: 4 & 27 \\
\hline
\end{tabular}




\begin{tabular}{|l|l|l|}
\hline & GS: 23 & \\
\hline $\begin{array}{l}\text { The total number of responses in } 5 \text { titles of Deddy Corbuzier's Podcast } \\
\text { videos }\end{array}$ & $\begin{array}{l}\text { H: } 88 \\
\text { GS: } 106\end{array}$ & 194 \\
\hline Note: $H=$ Host, GS = Guest Star & \\
\hline
\end{tabular}

Table 2.1 depicts the use of responses by speech partners in Deddy Corbuzier's YouTube podcast program to respond to language impoliteness based on the theme or title of the podcast program, guest stars presented, and language impoliteness responders. To be more specific, the researcher will explain based on the podcast program's title and the guest stars that are featured. "Are you certain it's a boy? What happened to the makeup? In the end, I got myself into a pickle" is the title of Deddy Corbuzier's first YouTube podcast program in which he invited Ivan Gunawan as a guest star. To deal with language impoliteness, the most common use of response is responding by attacking back (offensive countering). Deddy Corbuzier is the dominant respondent in this case. The power that he wields as the show's host is the driving force behind the offensive contering that has become the dominant way of responding to this podcast program. As the host, he has control over every role for questions posed to guest stars, including the direction of the conversation, even if the guests do not want to talk about it or appear to avoid certain questions. When the title of the podcast program with the guest star, Ivan Gunawan is considered, it tends to have more attacking gestures.

The position of the two is also the reason why the offensive counter-response is more common in this podcast with the responder, Deddy Corbuzier. They have been friends for a long time, dating back to their first appearances in the entertainment industry. As a result, even though their collaboration in one area is very limited, they are both heavily involved in a variety of activities that keep them close. This is due to the fact that they both work in the entertainment industry, albeit in different capacities. The many uses of the drilling strategy between the two demonstrate their lack of familiarity, indicating that the two are outspoken in discussing this theme because they have a background in their appearance that is almost identical. Your greeting also reinforces the fact that the two of them are on the verge of asking or answering each other's questions. On several occasions, harsh and impolite words were used, as well as attempts to make fun of each other, to indicate that the two were close.

As shown in table 2.1, the title of Deddy Corbuzier's YouTube podcast program is Adult Content, which invited guest stars from YouTubers and musicians, Onadio Leonardo. It is discovered that the dominance of the number of offensive and defensive contering responses is the same, but the respondent of language impoliteness with these two types of responses is different. The presenters mainly used the offensive contering response, while guest star Onadio Leonardo primarily used the defensive contering response.

The use of the offensive counter-response, which was mostly used by the presenters, occurred as Deddy Corbuzier attempted to reduce the distance between herself and the guest stars she only knew. In several instances, he stated that it was more dominant to use power in order to attack its guest stars. This podcast program's theme tends to discuss or comment on current events, both of which are unrelated to the problem. As a consequence, both of them merely pass judgment and express their respective points of view. Meanwhile, guest stars predominantly used the defensive counter response to defend their arguments and themselves in front of the press. The guest star did not make many attempts to attack Deddy Corbuzier because the two of them had just collaborated on a podcast for the first time, so they were still getting to know each other and trying to be friends.

Furthermore, the title of the podcast "He went completely insane. Djancok, sir!" with guest star Uus revealed that the dominant response used to respond to language impoliteness was offensive countering. This time, the respondent who used offensive contering the most was Uus as a guest star. 
The social distance between the two is close enough that they are close and have even been invited to the same event several times. The speech incident was dominated by the guest star, Uus as the owner of greater power than the host, Deddy Corbuzier because his background as a comedian influenced his utterances, which tended to ridicule and belittle Deddy Corbuzier. In terms of podcast titles, it appears that Uus is more hostile to Deddy Corbuzier, as evidenced by the use of the phrase "he went completely insane". Furthermore, the guest star, Uus rejects Deddy Corbuzier because it holds opposing views on the issues being debated. Other perspectives from Uus are frequently expressed, followed by attempts to retaliate or win debates with the host.

The title of the fourth podcast program that provided the data for this research is "Wow, it's insane! This is a prison. What the hell is going on?" - Yasonna Laoly Yasonna Laoly, who is serving as the Minister of Law and Human Rights for the second time, prefers the defensive counter-response strategy. In terms of their professional backgrounds, the social distance between them is quite large, prompting Deddy Corbuzier's efforts to close the gap by getting closer to the guest stars. In this case, the guest stars tend to defend themselves a lot due to their position as minister of law and human rights to discuss the overcrowding of prisons and the state of prisons in Indonesia, which is very concerning during this pandemic. The guest star also employs this defensive counter-response in an attempt to maintain his credibility in resolving legal and human rights issues, which are his mandate on two occasions. He mostly defended himself because he was well-versed in the field conditions that had occurred, as well as the flow of legal and human rights issues in Indonesia since his early days as minister. Yasonna Laoly typically responds to language impoliteness by defending himself and demonstrating his efforts and programs to do his best for all issues pertaining to law and human rights in Indonesia. Some of his efforts yielded results, while others were rejected due to policies that cannot be disclosed in detail.

Finally, the podcast program's title, "What if one generation is illiterate, bro?" features the Minister of Education and Culture, Nadiem Makariem, as a guest star, and discusses education during the COVID-19 pandemic from a source who is fully responsible for the current problems and education system in Indonesia. The dominant response found in the podcast title, according to the classification, is offensive contering performed by guest stars. This occurred as a result of the guest star's greater involvement in discussing higher education issues than the host, Deddy Corbuzier. Several speech incidents revealed that the guest star, Nadiem has more power than Deddy Corbuzier because it strikes back more often in response to language impoliteness. This is intended to support his claim that the policies implemented by the Minister of Education and Culture are correct. Meanwhile, Deddy Corbuzier carried out face attacks on guest stars because they represented the parents of guardians in Indonesia who also had children enrolled in distance learning due to the COVID-19 pandemic. He also bemoaned the shortcomings of long-distance education, which are shared by parents of students in Indonesia today.

In terms of the overall response to the data findings, guest stars were mostly responsible for the response to language impoliteness. The distribution of the total number of language impoliteness responses is shown below.

Table 2.2. The Total Number of Speech Partner Responses to Indecent Language in Deddy Corbuzier's YouTube Podcast Videos

\begin{tabular}{|l|l|l|l|l|l|}
\hline No. & \multicolumn{1}{|c|}{ Response } & H & \multicolumn{1}{|c|}{ GS } & Total & \% \\
\hline 1. & Responding by retaliating & 40 & 40 & 80 & 41.3 \\
\hline 2 & Maintaining your own face as you respond & 23 & 41 & 64 & 33 \\
\hline 3 & Accepting as the appropriate response & 19 & 18 & 37 & 19 \\
\hline
\end{tabular}




\begin{tabular}{|l|l|l|l|l|l|}
\hline 4 & Absence of response & 6 & 7 & 13 & 6.7 \\
\cline { 1 - 3 } & Total & $\mathbf{8 8}$ & $\mathbf{1 0 6}$ & $\mathbf{1 9 4}$ \\
\cline { 1 - 3 } & Percentage & $\mathbf{4 5 . 4}$ & $\mathbf{5 4 . 6}$ & $\mathbf{1 0 0 \%}$ \\
\hline
\end{tabular}

Table 2.2 shows the distribution of the number of responses, which shows that the guest stars are more sensitive to language impoliteness. This occurs because the guest stars are appropriate sources in the interview program, and their presence is intended to answer or respond to questions posed by the host. The capacity as a guest star also demonstrates that guest star responses are dominated by defensive countering or responding by showing one's own face and offensive countering or responding by attacking back. First, a defensive countering response occurs because, as a guest star who is presented, he is analogous to being a guest at an event; if there is a condition that threatens the face or an intentional face attack occurs, he will undoubtedly tend to defend himself. Efforts to defend oneself in response to language impoliteness are enhanced by guarding one's face and refraining from retaliating against profanity speakers. Second, guest stars can also respond by attacking back or offensive countering. Aside from attempting to save one's face, the effort to carry out this offensive counter-response also seeks to make face attacks on the speaker of language impoliteness, in this case the host.

\section{Conclusions}

Offensive countering can be a response to counterattack the speech partners. This response occurs because the speech partner disagrees with the speaker's language impoliteness. This response aims to counterattack the speaker's loss of face toward the impoliteness act so that the speech partner feels victorious due to the backlash. The variations in the data sources include the response that strikes back with curses as an expression of annoyance, ignores or considers the speech partner unimportant, uses sentences that state evidence, denies and blames the speech partner, strikes back with thorny questions, and shows annoyance at the speech partner, and utterances with the intent of threatening.

Defensive countering is a method of defending one's argument and fighting evasively in response to face-to-face attacks. In other words, the speech partner (the receiver) strengthens his or her position and explains something true without retaliating against the speaker. The defensive response has four variations: defending one's arguments by believing that he or she is innocent, seeing that he or she is different from others (more importantly), expressing ideas, and demonstrating an action that places himself or herself in a safe situation.

Participants can choose to accept face-to-face attacks or language impoliteness in addition to a counter-response option. In this case, the participants agree to the language impoliteness and interpret it to mean that the act of language impoliteness aims to reduce the number of face-to-face attacks. Accepting the impoliteness act, confirming the speech, accusing the speech partner, and choosing to use the solution are all variations on face-to-face attacks.

\section{References}

Bousfield, D. (2008). Impoliteness in interaction, 167. John Benjamins Pub..

Bousfield, D., \& Locher, M. A. (Eds.). (2008). Impoliteness in language: Studies on its interplay with power in theory and practice (Vol. 21). Walter de Gruyter. 
Brown, P., Levinson, S. C., \& Levinson, S. C. (1987). Politeness: Some universals in language usage (Vol. 4). Cambridge university press.

Clark, H. H. (1996). Using language. Cambridge university press.

Culpeper, J., Bousfield, D., \& Wichmann, A. (2003). Impoliteness revisited: With special reference to dynamic and prosodic aspects. Journal of pragmatics, 35(10-11), 1545-1579.

Dafiqi, M. A. (2016). Analisis Strategi Ketidaksantunan yang Ditemukan dalam Skrip Film Carnage. Jurnal Universitas Jember.

Fatimah, N. (2014). Ketidaksantunan Culpeper dalam Berbahasa Lisan di Sekolah. Prosiding Seminar Nasional, Universitas Muhammadiyah Surakarta.

Fhitri, W. (2014). Ketidaksantunan dalam Pesan Singkat Mahasiswa kepada Dosen. Jurnal Gramatika, 4, 241-261.

Haryanto, S. (2015). Beberapa Tindak Ketidaksantunan dalam Masyarakat Jawa. Jurnal Prasasti II, hlm 56-60.

Hefdzil, A. M. (2017). Kesantunan dan Ketidaksantunan Berbahasa Masyarakat Sunda dalam Dialog Percakapan pada Acara Kunjungan Keluarga di Beberapa Tempat di Jawa Barat. Jurnal AlTsaqafa, 14(1).

House, J., \& Kádár, D. Z. (2021). German and Japanese war crime apologies: A contrastive pragmatic study. Journal of Pragmatics, 177, 109-121. https://doi.org/10.1016/j.pragma.2021.02.001

Huang, Y. (2007). Pragmatics. New York: Oxford University Press.

Inderasari, et al. (2019). Bahasa Sarkasme Netizen dalam Komentar Akun Instagram Lambe Turah. Jurnal Semantik, 8(1).

Jumadi, Y. (2015). Wujud Kesantunan dan Ketidaksantunan Berbahasa Pedagang di Pasar Sentra Antasari. Jurnal Bahasa, Sastra dan Pembelajarannya.

Karisma, G. I. (2013). Ketidaksantunan Berbahasa Indonesia dalam Sidang Tindak Pidana Korupsi Kasus Wisma Atlet Berdasarkan Prinsip Kesantunan Leech. Jurnal Universitas Negeri Jember.

Leech, G. (1983). The Principles of pragmatics. New York: Longman Group Limited.

Leech, G. (1993). Prinsip-prinsip pragmatik (edisi terjemahan oleh M. D. D. Oka). Jakarta: UI Press.

Levinson, S.C. (1983). Pragmatics. Cambridge: Cambridge University Press.

Liu, F., Han, D., Kádár, D. Z., \& House, J. (2021). The expressions '(M)minzu-zhuyi' and 'Nationalism': A contrastive pragmatic analysis. Journal of Pragmatics, 174, 168-178. https://doi.org/10.1016/j.pragma.2020.12.013

Makin, S. (2021). The research-practice gap as a pragmatic knowledge boundary. Information and Organization, 100334. https://doi.org/10.1016/j.infoandorg.2020.100334

Maryati, M. (2013). Realisasi Keidaksantunan Berbahasa dalam Komunikasi Remaja dan Implikasinya terhadap Pembelajaran Bahasa Indonesia. Jurnal Kata, 1(8).

Matsumoto, Y., \& Canagarajah, S. (2020). The use of gesture, gesture hold, and gaze in trouble-in-talk among multilingual interlocutors in an English as a lingua franca context. Journal of Pragmatics, 169, 245-267. https://doi.org/10.1016/j.pragma.2020.08.015

Maulidi, A. (2015). Ketidaksantunan Berbahasa pada Media Jejaring Sosial Facebook. Jurnal Multilingual. 
Meng, P. (2005). Podcasting and Vodcasting. University of Missouri IAT Services White Paper.

Mey, L. Y. (1993). Pragmatics: An Introduction. Blackwell: Oxford UK and USA Cambridge.

Nugroho, M. (2009). Konteks dalam Kajian Pragmatik dalam Peneroka Hakikat Bahasa. Yogyakarta: Universitas Sanata Dharma.

Nugroho, M. (2013). Data dan Metode Pemerolehan Data dalam Penelitian Pragmatik. Proceeding Seminar Internasional, hlm 503-506.

Oatey, H. S. (2000). Culturally Speaking. New York: Continuum.

Purnanto, et al. (2015). Wujud Ketidaksantunan Berbahasa dalam Persidangan Pidana di Surakarta. Konferensi Nasional Bahasa dan Sastra III, hlm 62-66

Rahardi, R. K. (2020). Pragmatic meanings of javanese phatic marker 'sampun': culture-specific pragmatic perspective. RETORIKA: Jurnal Bahasa, Sastra, Dan Pengajarannya, 13(1), 125. https://doi.org/10.26858/retorika.v13i1.11227

Rinzat, Muhammad. (2018). "Pudarnya Kaidah Kesantunan pada Masyarakat Indonesia". Jurnal Lingua Franca:Bahasa, Sastra dan Pengajarannya, 6(2).

Shim, et al. (2007). Podcasting for e-learning communication and delivery. Journal of Industrial Management and Data Systems, 107(4). Emerald Group Publishing. Technology Studentss, Proceedings of the Student Experience Conference, D.H.R. Spennemann and L. Burr (eds.), Sept. 5-7, 2005, 59-71.

Stalnaker, R. (1974). Context and content. New York: Oxford University Press.

Subroto, E. (1999). Ihwal relasi makna: Beberapa kasus dalam bahasa indonesia. Seminar Nasional I Semantik Sebagai Dasar Fundamental Pengkajian Bahasa, Pascasarjana UNS Surakarta, 26-27 Pebruari 1999.

Subroto, E. (2017). Pengantar studi semantik dan pragmatik. Surakarta: Cakrawala Media.

Sudaryanto, S. (1993). Metode dan Aneka Teknik Analisis Bahasa. Yogyakarta: Duta Wacana University Press.

Suryanti, S. (2019). Impolite Responses to Donald Trump's Posts on Instagram. Jurnal Idebahasa, $1(1)$.

Tasliati, T. (2015). Strategi Kesantunan dan Ketidaksantunan dalam Tindak Tutur Direktif Guru. Jurnal Aksara, 16(1).

Tasliati, T. (2019). Analisis Ketidaksantunan Berbahasa pada Unggahan dalam Grup Daring Jual-Beli di Kota Tanjungpinang. Jurnal Genta Bahtera, 4(2).

Widara, P. A. (2018). Ancangan Model Pembelajaran Pragmatik Klinis Berdasarkan Analisis Ketidaksantunan Berbahasa Siswa SMA di Tasikmalaya. Jurnal Literasi, 2(1).

Wigati, A. (2017). Strategi Ketidaksantunan Bertindak Tutur Direktif Anak Sekolah Menengah Pertama dan Implikasinya dalam Pembelajaran Bahasa Indonesia. Jurnal UMS.

Wijayanto, A. (2018). Impoliteness in English Foreign Language Complaints: Exploring Intentions and Motivating Factors. Jurnal Lingua Cultura.

Wijayanto, A. (2019). Ketidaksantunan Berbahasa: Penggunaan Bahasa Kekerasan di Sinetron Bertema Kehidupan Remaja. Prosiding Seminar Nasional, 115-125. 
Wulandari, Y. (2016). Analisis Bentuk Pelanggaran Maksim Tuturan Tokoh Cerpen Harga Seorang Perempuan Karya Oka Rusmini Sebagai Materi Otentik Pembentukan Karakter. Jurnal Buana Bastra, 3(1), 59-72.

Yule, G. (1996). Pragmatics. Oxford: Oxford University Press.

Zamzani, Z. (2007). Kajian Sosiopragmatik. Yogyakarta: Cipta Pustaka.

Zhang, J., \& Wu, Y. (2020). Only youxie think it is a nice thing to say: Interpreting scalar items in face-threatening contexts by native Chinese speakers. Journal of Pragmatics, 168, 19-35. https://doi.org/10.1016/j.pragma.2020.06.008

\section{AUTHOR BIODATA}

Anisah Hanif, Sebelas Maret University, Surakarta, Indonesia. The first author of this article is Anisah Hanif, S.S., who was born on September 10, 1995 in Sukoharjo. She obtained a degree in Indonesian Literature from the Faculty of Humanities at Universitas Sebelas Maret Surakarta (UNS), Indonesia. She is currently pursuing her studies at the Postgraduate Study Program of Linguistics, Faculty of Humanities, Sebelas Maret University, Surakarta, Indonesia with a focus on descriptive linguistics. She is interested in linguistic fields such as pragmatics, semantics, syntax, and discourse analysis. Her scientific publications include The Indecency Strategy in the Masterchef of the Indonesian Food Testing Session (2018) in the Indonesian Literature Journal, Universitas Sebelas Maret Surakarta (UNS), The Use of Conjunctions in Kompas Selected Short Stories by Seno Gumira Ajidarma (2020), and Prepositional Phrases in a Collection of Short Stories of Senja and Bloody Love by Seno Gumira Ajidarma (2020), both of which were published in the 2020 SEMANTICS Proceedings (National Seminar on Linguistics and Literature) hosted by Sebelas Maret University Surakarta, Indonesia.

Dwi Purnanto, Sebelas Maret University, Surakarta, Indonesia. Dr. Dwi Purnanto, M.Hum. was born in Boyolali on November 11, 1961, and obtained his doctorate in descriptive linguistics and master's degree in descriptive linguistics from the Faculty of Cultural Sciences at Sebelas Maret University, Surakarta, Indonesia. His scientific works or research publications are listed below, including Phatic Communication Politeness of Greating Arek Culture on Instagram Account: Pragmatics (2018) in International Journal of Multicultural and Multireligious Understanding, Politeness Strategies in Directive Speech Acts in Local Indonesian Parliament Assembly Proceedings (2019) at International Journal of English Linguistics, Linguistic Landscape on the Street Name in Malang City (2020) in Utopia y Praxis Latinomericana (Q2), and Politeness Strategies in Negative Response to Criticism in the Javanese Cultural Community (2020) at Opcion (Q3). Some of the awards received include: The master's degree with honors (cum laude) in Linguistics (2002) from the Postgraduate Program of Universitas Sebelas Maret Surakarta (UNS), the Doctoral Degree Award (2010) by the Chancellor of Sebelas Maret University, and the Satya Lencana Award after three decades of employment (2018) by the President of the Republic of Indonesia.

Miftah Nugroho, Sebelas Maret University, Surakarta, Indonesia. Dr. Miftah Nugroho, M.Hum., was born on July 25, 1977 in Surakarta and he is a linguistics lecturer at the Indonesian Literature Study Program, Faculty of Humanities, Sebelas Maret University, Surakarta, Indonesia. In 2000, he obtained his undergraduate diploma from the Department of Indonesian Literature at the Faculty of Letters, Sebelas Maret Surakarta (UNS), Indonesia. Then, in 2003, he graduated from the Graduate School's Linguistics Study Program, Universitas Gadjah Mada, Yogyakarta, Indonesia. In 2018, he obtained his doctorate from the Postgraduate Linguistic Study Program, Sebelas Maret University, Surakarta, Indonesia. His scientific works include, The Strategy for the Delivery of Dai's Speech Actions to the Dialogical Da'wah Discourse in Surakarta (2019), The Study of Speech Actions on Didi Kempot Song Lyrics (2020), the Study of the Director's Speech on SMS from NonGovernmental Organizations during the Covid-19 Pandemic (2020), and The Cooperative Principles of Dialogic Da'wah Discourse in the City of Surakarta (2020). 